\title{
CUTTING MANAGEMENT VERSUS BIOMASS AND CARBON STOCK OF OAK UNDER HIGH DENSITY PLANTATION IN CENTRAL HIMALAYA, INDIA
}

\author{
YADAV, R. P. ${ }^{1 *}$ - BISHT, J. K. ${ }^{1}-$ PANDEY, B. M. ${ }^{1}-$ KUMAR, A. ${ }^{2}-$ PATTANAYAK, A. ${ }^{1}$ \\ ${ }^{1}$ ICAR-Vivekananda Parvatiya Krishi Anusandhan Sansthan, Almora-263601, India \\ ${ }^{2}$ ICAR-Sugarcane Breeding Institute Research Centre, Civil Station Post, Kannur-670002, \\ Kerala, India \\ *Corresponding author \\ e-mail: rams34052@gmail.com \\ (Received $4^{\text {th }}$ Dec 2015; accepted $12^{\text {th }}$ Apr 2016)
}

\begin{abstract}
Tree growth and productivity are influenced by silvicultural strategies such as tree density and cutting management, which determine the potential of tree species to store carbon in the vegetation. A field experiment was conducted at Vivekananda Institute of Hill Agriculture, Almora, India in a 30-yearold Quercus leucotrichophora to evaluate the changes in vegetation carbon pools as a function of four cutting management $\left(1 \mathrm{~m}, 2 \mathrm{~m}\right.$, local practice, and above $1 / 3^{\text {rd }}$ part undisturbed), under high density plantation $(1.0 \mathrm{~m} \times 1.0 \mathrm{~m})$. Tree cutting management significantly $(<0.01)$ influenced the carbon stocks of $Q$. leucotrichophora trees. Total vegetation (aboveground + below ground) carbon stock was highest for the above $1 / 3^{\text {rd }}$ part undisturbed $\left(356.9 \mathrm{Mg} \mathrm{ha}^{-1}\right)$ and lowest in the cutting at $1 \mathrm{~m}\left(86.7 \mathrm{Mg} \mathrm{ha}^{-1}\right)$. Overall, less disturbance to stands promote carbon storage, but intense cutting management (e.g., cutting at $1 \mathrm{~m}$ ) may adversely affect tree growth and productivity, reducing vegetation carbon pools. Cutting management effects are very much visible on carbon stock of $Q$. leucotrichophora under high density plantation. By extension, stand cutting exerts negative or positive feedbacks on biomass accretion, which may also influence the amount of carbon sequestered by the trees.
\end{abstract}

Keywords: biomass, carbon stock, cutting management, high density plantation, Himalaya, oak plantation

\section{Introduction}

The United Nations Framework Convention on Climate Change (UNFCCC) is one of the instruments of the global efforts to stabilize the greenhouse gases (GHGs) in the atmosphere (UNFCCC, 1993). Among the climate change lessening strategies trees are the economical means to capture and store atmospheric carbon dioxide $\left(\mathrm{CO}_{2}\right)$ in vegetation (Malhi et al., 2008) which has encouraged screening of trees with high carbon (C) storage potential (Delaney et al., 1997; Paquette et al., 2009). Multipurpose tree species such as Quercus leucotrichophora A. Camus have an imperative position for C storage potential (Singh et al., 2014). Tree management practices and site characteristics (Nair et al., 2010) in addition to the inherent production potential of the species affect $\mathrm{C}$ sequestration (removal of $\mathrm{CO}_{2}$ from the atmosphere). In a given species, according to edapho-climatic conditions various silvicultural practices are adopted to improve tree productivity, which also alters $\mathrm{C}$ sequestration potential (Dixon, 1997; Jiménez et al., 2011; Coletta et al., 2016).

Oaks (Quercus spp.) are the dominant, climax tree species of the moist temperate forests of the Indian Himalayan region (Troup, 1921), where about 35 species of Quercus are extensively distributed between 1000-3500 $\mathrm{m}$ elevations. $Q$. leucotrichophora is an evergreen tree, locally known as "Banj oak" and it is a valuable 
keystone species with great societal relevance (Ramakrishnan, 2001). Banj is among the main forest-forming species in the densely populated mid-altitudinal zones of the Central Himalaya and provides a variety of ecosystem services (Zobel and Singh, 1997; Sharma et al., 2009). The oaks, particularly Q. leucotrichophora is intricately associated not only with agro-ecosystems but also with the life support systems of the inhabitants of the hills in the Himalaya (Makino, 2011). High calorific value of banj wood makes it an excellent fuel, its leaves are palatable which makes them major source of cattle fodder in the winter and dry seasons (Negi et al., 1997; Yadav and Bisht, 2013) and can be correlated with natural springs and wildlife (Singh, 1981).

Information on the effects of planting density and thinning on $\mathrm{C}$ sequestration by multipurpose tree species is scarce (Jandl et al., 2007) but on conifers particularly in Europe are available (Marziliano et al., 2015; Coletta et al., 2016); similarly, thinning and pruning interaction may influence growth and development of tree by affecting resources availability (Beadle et al., 2007). However, information on the impact of various cutting management levels in combination with high density plantation (HDP) on the biomass and carbon stock of woody perennial based land use systems is still unavailable. Despite the widespread use of $Q$. leucotrichophora in the Himalayan region (Yadav and Bisht, 2013) species-specific information on HDP and cutting management regimes and its impact on $\mathrm{C}$ sequestration are deficient. The $Q$. leucotrichophora plantation, like farm plantations of other species in Himalayan region, is multipurpose. Besides timber products and diversification of farm income the objective is to deliver a range of environmental benefits.

The focus of this article is cutting management influence in Quercus leucotrichophora on biomass and carbon stock under HDP of the Central Himalaya. A field investigation was carried out to evaluate the aboveground and belowground (root) $\mathrm{C}$ stocks of this species under HDP with tree cutting management practices (i.e. fodder harvesting techniques) in the Central Himalayan region of India. In this paper, we report growth, biomass $\mathrm{C}$ stocks and $\mathrm{C}$ sequestration rate of HDP of Q. leucotrichophora under different cutting management practices.

\section{Materials and Methods}

\section{Study area}

The study was conducted at experimental farm Hawalbagh $\left(29^{\circ} 36^{\prime} \mathrm{N}\right.$ and $79^{\circ} 40^{\prime} \mathrm{E}$, $1250 \mathrm{~m}$ amsl) of Vivekananda Parvatiya Krishi Anusandhan Sansthan, Almora, India. The site experiences a sub-temperate climate and annual rainfall of $1100 \mathrm{~mm}$ with $96+$ rainy days most of which is received during the monsoon season (June-September) and the remaining from October to May. Temperature ranges between $32{ }^{\circ} \mathrm{C}$ during summer and the minimum temperature from below freezing during winter. The experimental site was neutral in $\mathrm{pH}(6.6)$ and had $0.85 \%$ organic $\mathrm{C}(0-15 \mathrm{~cm})$. The $\mathrm{pH}$ of each soil was determined using a digital $\mathrm{pH}$ meter and Walkey's and Blacks titration method (Jackson, 1967) was used to measure soil organic carbon.

\section{Plantation}

Q. leucotrichophora was planted at this site in 1983 with high density at a spacing of $1 \times 1 \mathrm{~m}$ and managed properly for many years. Seedling survival was excellent and mortality, if any, was replaced immediately. In the year of 1997 four cutting 
management, i.e. coppicing at $1 \mathrm{~m}$ height, pollarding at $2 \mathrm{~m}$ height, local practice, and keeping above $1 / 3^{\text {rd }}$ part undisturbed practices introduced in the plantation for fodder harvesting. So, in this article cutting management practices means fodder harvesting techniques which are being used in this trial. Fodder harvested during lean period, i.e. winter season due to drying of grasses and rainfed farming no source of fodder than trees in mid hills of Himalaya. Here in this article we have used some terms such as 'least disturbed tree' synonymous with 'less intense cutting' means minimum biomass removed from the trees such as local practice and keeping above $1 / 3^{\text {rd }}$ part undisturbed of the trees and 'increased disturbance' synonymous with 'high intense cutting' means maximum biomass of the trees removed such as coppicing at $1 \mathrm{~m}$ height and pollarding at $2 \mathrm{~m}$ height of the trees. The trial was laid out in a randomized block design with replicates block wise.

\section{Estimation of carbon stocks}

In the plantation a total of 240 trees, comprising 60 trees from each plot of cutting management practices were measured for girth at breast height (gbh) except for basal area in $1 \mathrm{~m}$ height cutting management plots and height with the help of measuring tape and Ravi multimeter, respectively. The gbh and basal area is than converted to diameter at breast height $(\mathrm{dbh})$ and basal diameter. Equation, Volume $/ \mathrm{d}^{2}=5009470+0.00563 / \mathrm{d}^{2}$ (FSI, 2009) was used to calculate volume and biomass measured by multiplying volume with tree density. Below ground biomass of trees was calculated by Cairns (1997) and as per the IPCC guidelines. Carbon stock was estimated by considering carbon content 0.45 (Magnussen and Reed, 2004) and biomass carbon dioxide by multiplying with a factor 3.67. Standing stock of biomass and $\mathrm{C}$ was converted on area basis (per ha) by multiplying the mean tree values with the corresponding density of trees.

\section{Statistical analysis}

Data from the completely randomized block design experiment were analyzed using one way analysis of variance (AGRES ANOVA).

\section{Results and Discussion}

\section{Growth}

The mean height and diameter per tree among different cutting management practices was significantly highest $(10.14 \mathrm{~m}$ and $12.21 \mathrm{~cm})$ for the trees which were kept $1 / 3^{\text {rd }}$ top portion undisturbed followed by others and lowest $(2.02 \mathrm{~m}$ and $5.35 \mathrm{~cm})$ for trees coppiced at $1 \mathrm{~m}$ height, respectively (Table 1). Though, the height of trees coppiced at $1 \mathrm{~m}$ was on par with trees pollarded at $2 \mathrm{~m}$ height. Similar results were also obtained for mean volume per tree significantly highest $\left(0.0833 \mathrm{~m}^{3}\right)$ for the trees kept $1 / 3^{\text {rd }}$ top portion undisturbed followed by other practices and lowest $\left(0.0202 \mathrm{~m}^{3}\right)$ for trees which were coppiced at $1 \mathrm{~m}$ height which was on par with the pollarding at $2 \mathrm{~m}$ height among different cutting management practices. 
Table 1. Effect of cutting management on the growth of oak in Central Himalaya

\begin{tabular}{lccc}
\hline Treatment & Height $(\mathbf{m})$ & Diameter $(\mathbf{c m})$ & Mean volume $\left(\mathbf{m}^{\mathbf{3}}\right)$ \\
\hline Coppicing at $1 \mathrm{~m}$ & 2.02 & 5.35 & 0.0202 \\
Local & 6.76 & 8.11 & 0.0396 \\
Pollarding at $2 \mathrm{~m}$ & 2.93 & 6.70 & 0.0288 \\
$1 / 3^{\text {rd }}$ top portion undisturbed & 10.14 & 12.21 & 0.0833 \\
LSD $(.01)$ & 1.32 & 1.77 & 0.0212 \\
\hline
\end{tabular}

The mean height, diameter and volume decreased with increasing cutting intensity, meaning growth parameters were less in more intense cutting management practices, i.e. cutting at $1 \mathrm{~m}$ and $2 \mathrm{~m}$ height as compared to for the trees which were managed with less intense cutting, i.e. $1 / 3^{\text {rd }}$ top portion undisturbed and local practice. In general, removal of higher proportion of leaves during pruning operations may adversely affect photosynthetic rates and would depress tree growth including decrease in annual diameter growth (Gyenge et al., 2010). The volume on area basis showed the same trend as the mean height and diameter and ranged from 202 to $833 \mathrm{~m}^{3} \mathrm{ha}^{-1}$ for different cutting management practices (Figure 1).

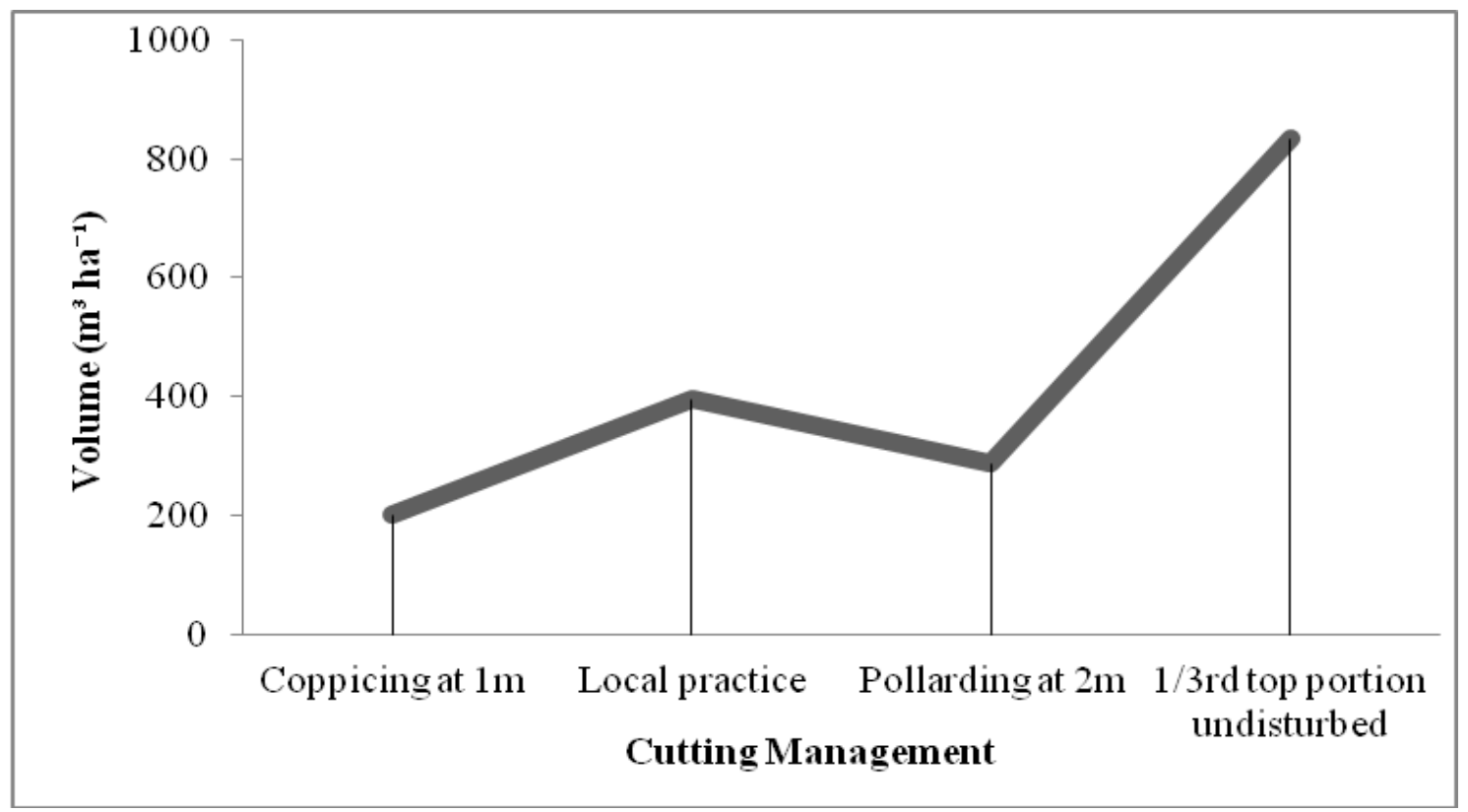

Figure 1. Total volume of oak influenced by cutting management in Central Himalaya

\section{Biomass accumulation}

Highly significant $(\mathrm{p}<.01)$ variation in total biomass was observed among different cutting management practices. Total tree biomass including aboveground and belowground biomass, ranged from 192.6 to $793.2 \mathrm{Mg}^{-1}$ (Table 2). The Least disturbed trees, i.e. $1 / 3^{\text {rd }}$ top portion undisturbed practice recorded the significantly highest (793.2 $\mathrm{Mg} \mathrm{ha}^{-1}$ ) total tree biomass accumulation and it declined with increasing tree disturbance, i.e. coppicing at $1 \mathrm{~m}$ recorded significantly lowest $\left(192.6 \mathrm{Mg} \mathrm{ha}^{-1}\right)$ in the form of cutting management practices. The results are in conformity with the 
findings of Singh et al. (2014); Yadav and Bisht (2014). It is well known that limitations imposed by cutting management of trees on the lateral expansion and roots may restrain resource acquisition potential of trees leading to reductions in their biomass production. Similarly in a five year old plantation of Shisham with 625 trees $^{-1} \mathrm{a}^{-1}$ the total vegetation biomass was $58.7 \mathrm{Mg} \mathrm{ha}{ }^{-1}$ and annual biomass accumulation $12.6 \mathrm{Mg} \mathrm{ha}^{-1} \mathrm{yr}^{-1}$ (Lodhiyal et al., 2002), which is quite low than this study.

Table 2. Cutting management influence on biomass of oak in Central Himalaya

\begin{tabular}{lccc}
\hline Treatment & \multicolumn{3}{c}{ Biomass $\left(\mathbf{M g ~ h a}^{-1}\right)$} \\
\cline { 2 - 4 } & Aboveground & Belowground & Total \\
\hline Coppicing at $1 \mathrm{~m}$ & 151.6 & 40.9 & 192.6 \\
Local & 296.7 & 80.1 & 376.8 \\
Pollarding at $2 \mathrm{~m}$ & 215.8 & 58.3 & 274.1 \\
$1 / 3^{\text {rd }}$ top portion undisturbed & 624.6 & 168.6 & 793.2 \\
LSD $(.01)$ & 158.8 & 42.8 & 201.7 \\
\hline
\end{tabular}

\section{Carbon stock}

Total plantation $\mathrm{C}$ stocks (aboveground + belowground) followed a reverse trend and it decreased with increased disturbance in the form of cutting management practices (Table 3). Almost one and a half-fold increase in $\mathrm{C}$ stocks have been observed in the pollarding at $2 \mathrm{~m}\left(123.4 \mathrm{Mg} \mathrm{ha}^{-1}\right)$ compared to that of the cutting at $1 \mathrm{~m}\left(86.7 \mathrm{Mg} \mathrm{ha}^{-1}\right)$ and two fold in the $1 / 3^{\text {rd }}$ top portion undisturbed $\left(356.9 \mathrm{Mg} \mathrm{ha}^{-1}\right)$ as compared to local practice $\left(169.6 \mathrm{Mg} \mathrm{ha}^{-1}\right)$.

Table 3. Carbon stocks of oak as influenced by cutting management in Central Himalaya

\begin{tabular}{|c|c|c|c|c|}
\hline \multirow[t]{2}{*}{ Treatment } & \multicolumn{3}{|c|}{ Carbon stock $\left(\mathrm{Mg} \mathrm{ha}^{-1}\right)$} & \multirow{2}{*}{$\begin{array}{l}\text { C sequestration } \\
\text { rate }\left(\mathrm{Mg} \mathrm{ha}^{-1} \mathrm{yr}^{-1}\right)\end{array}$} \\
\hline & Aboveground & Belowground & Total & \\
\hline Coppicing at $1 \mathrm{~m}$ & 68.1 & 18.4 & 86.7 & 2.9 \\
\hline Local & 133.4 & 36.1 & 169.6 & 5.7 \\
\hline Pollarding at $2 \mathrm{~m}$ & 97.2 & 26.2 & 123.4 & 4.1 \\
\hline $1 / 3^{\text {rd }}$ top portion & 2812 & & & 11.9 \\
\hline undisturbed & 281.2 & 75.9 & 356.9 & \\
\hline LSD (.01) & 71.4 & 19.3 & 90.7 & 3.4 \\
\hline
\end{tabular}

Cutting at $1 \mathrm{~m}$ height depressed two fold and four fold $\mathrm{C}$ stock and pollarding at $2 \mathrm{~m}$ height of the tree reduced half fold and almost three fold $\mathrm{C}$ stock in comparison to local and $1 / 3^{\text {rd }}$ top portion undisturbed practices, respectively. Carbon stocks being a function of the overall tree growth (Table 1), this is not surprising. Singh et al. (2014) reported the impact of human-induced small-scale disturbances (lopping of branches and leaf removal) adversely impacts the functioning of banj oak (Quercus leucotrichophora A. Camus) forests of Central Himalaya. Majid and Paudyal (1992) noted reductions in tree growth when crown length removal from below exceeded $40 \%$ in the A. mangium plantation of peninsular Malaysia. The biomass carbon $\mathrm{Co}_{2}$ mitigation by the Oak high density plantation followed the trend of biomass and carbon stock and varied between 317-1306 Mg ha ${ }^{-1}$ among different cutting management practices (Figure 2). 


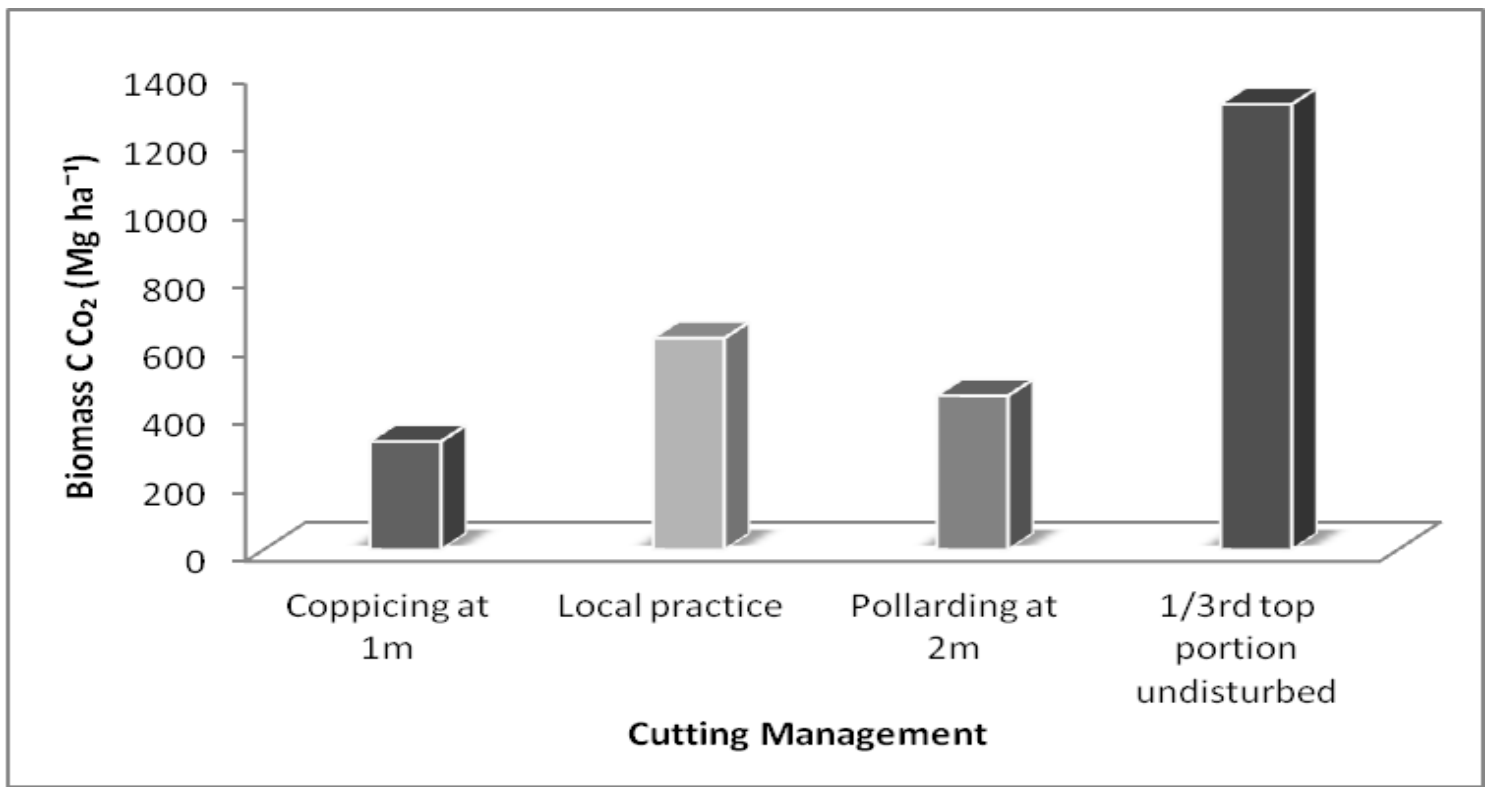

Figure 2. Cutting management influence on total biomass $\mathrm{CO}_{2}$ in Central Himalaya

Biomass and carbon stock estimates for 30 year old $Q$. leucotrichophora in the present study reveal its potential as a promising tree species for $\mathrm{C}$ sequestration. Higher rate of total $\mathrm{C}$ sequestration was with the minimal disturbance cutting management practice, i.e. in $1 / 3^{\text {rd }}$ top portion undisturbed $\left(11.9 \mathrm{Mg} \mathrm{ha}^{-1} \mathrm{yr}^{-1}\right)$ followed by other practices and least in cutting at $1 \mathrm{~m}$ height $\left(2.9 \mathrm{Mg} \mathrm{ha}^{-1} \mathrm{yr}^{-1}\right)$ which was the intense cutting management practice (Table 3). The varying rate of $\mathrm{C}$ sequestration of plantations can be attributed to their differential cutting management practices. Results of the $\mathrm{C}$ sequestration rates were almost within range to those obtained in earlier studies (KTGAL, 2004; Yadav and Bisht, 2014; Yadav et al., 2015). According to Table 4 pearson correlation shows that diameter is highly correlated to volume, total biomass and carbon sequestration rate of oak under high density plantation.

Table 4. Pearson correlations among different parameters of oak under high density plantation

\begin{tabular}{lccccc}
\hline Parameters & Height & Diameter & Volume & Total biomass & $\begin{array}{c}\text { C sequestration } \\
\text { rate }\end{array}$ \\
\hline Height & 1 & $.970^{*}$ & $.951^{*}$ & $.951^{*}$ & $.951^{*}$ \\
Diameter & $.970^{*}$ & 1 & $.995^{* *}$ & $.995^{* *}$ & $.995^{* *}$ \\
Volume & $.951^{*}$ & $.995^{* *}$ & 1 & $1.000^{* *}$ & $1.000^{* *}$ \\
$\begin{array}{l}\text { Total biomass } \\
\text { C sequestration } \\
\text { rate }\end{array}$ & $.951^{*}$ & $.995^{* *}$ & $1.000^{* *}$ & 1 & $1.000^{* *}$ \\
\hline
\end{tabular}

\section{Conclusion}

This paper shows the potential of $Q$. leucotrichophora, a Himalayan woody species, to sequester atmospheric $\mathrm{CO}_{2}$ and influence of cutting management practices on high 
density plantation $\mathrm{C}$ pools. Intense cutting management practices, i.e. cutting at $1 \mathrm{~m}$ and $2 \mathrm{~m}$ height depressed overall tree growth, biomass and $\mathrm{C}$ stocks of this species. On the other hand the less disturbed, i.e. $1 / 3^{\text {rd }}$ top portion undisturbed and local practices which stored good amount of $\mathrm{C}$ in plantation. Local inhabitants of Himalayan region can harvest fodder from this species while still allowing the storage of carbon by planting and choosing appropriate cutting management practices in agroforest for sustainable development. Overall, species, site, age and good silvicultural practices may favor tree growth and productivity and promote plantation $\mathrm{CO}_{2}$ sequestration and $\mathrm{C}$ conservation.

\section{REFERENCES}

[1] Beadle, C., Barry, K., Hardiyanto, E., Irianto, R., Junarto Mohammed, C., Rimbawanto, A. (2007): Effect of pruning Acacia mangium on growth, form and heart rot. -For. Ecol. Manage. 238:261-267.

[2] Cairns, M.A., Brown, S., Helmer, E.H., Baumgardner, G.A. (1997): Root biomass allocation in the world's upland forests. -Oecologia 111:1-11.

[3] Coletta, V., Menguzzato, G., Pellicone, G., Veltri, A. Marziliano, P.A. (2016): Effect of thinning on above-ground biomass accumulation in a Douglas-fir plantation in southern Italy. -Journal of Forestry Research. In press

[4] Delaney, M., Brown, S., Lugo, A.E., Torres-Lezama, A., Bello-Quintero, N. (1997): The distribution of organic carbon in major components of forests located in five life zones of Venezuela. -Journal of Tropical Ecology 13: 697-708.

[5] Dixon, R.K. (1997): Silvicultural options to conserve and sequester carbon in forest systems: Preliminary economic assessment. -Crit. Rev. Environ. Sci. Technol. 27:139149.

[6] FSI [Forest Survey of India]. (2009): Forest Survey of India-Annual Report, Ministry of Environment and Forest, Dehradun.

[7] Gyenge, J.E., Fernańdez, M.E., Schlichter, T.M. (2010): Effect of stand density and pruning on growth of ponderosa pines in NW Patagonia, Argentina. -Agroforest. Syst. 78:233-241.

[8] Jackson, M.L. (1958): Soil chemical analysis. -Asia Publishing House, New Delhi, p 498.

[9] Jandl, R., Lindner, M., Vesterdal, L., Bauwens, B., Baritze, R., Hagedorn, F., Johnsong, D.W., Minkkinen, K., Byrne, K.A. (2007): How strongly can forest management influence soil carbon sequestration? -Geoderma 137(3-4):253-268.

[10] Jiménez, E., Vega, J.A., Fernández, C., Fonturbel, T. (2011): Is pre-commercial thinning compatible with carbon sequestration? A case study in a maritime pine stand in northwestern Spain. -Forestry 84:149-157.

[11] KTGAL [Kyoto Think Global Act Local]. (2004): Project Report: 2003-2004 [submitted to International Centre for Integrated Mountain Development, Kathmandu, Nepal]. Nainital, India: Central Himalayan Environment Association.

[12] Lodhiyal, N., Lodhiyal, L.S., Pangtey, Y.P.S. (2002): Structure and function of Shisham forests in Central Himalaya, India: dry matter dynamics. -Ann. Bot. 89 (41): 54.

[13] Magnussen, S., Reed, D. (2004): Modelling for estimation and monitoring (FAO-IUFRO, 2004).

[14] Majid, N.M., Paudyal, B.K. (1992): Pruning trial for Acacia mangium Wild. plantation in Peninsular Malaysia. -For. Ecol. Manage. 47:285-293.

[15] Makino, Y. (2011): Lopping of Oaks in Central Himalaya, India. -Mountain Research and Development 31(1):35-44.

[16] Malhi, Y., Roberts, J.T., Betts, R.A., Killeen, T.J., Li, W., Nobre, C.A. (2008): Climate change, deforestation, and the fate of the Amazon. -Science 319:169-172. 
[17] Marziliano, P.A., Coletta, V., Menguzzato, G., Nicolaci, A., Pellicone, G., Veltri, A. (2015): Effects of planting density on the distribution of biomass in a douglas-fir plantation in southern Italy. -iForest 8:368-376.

[18] Nair, P.K.R., Nair, V.D., Kumar, B.M., Showalter, J.M. (2010): Carbon sequestration in agroforestry systems. -Adv. Agron. 108:237-307.

[19] Negi, A.K., Bhatt, B.P,, Todaria, N.P., Saklani, A. (1997): The effects of colonialism on forests and the local people in the Garhwal Himalaya, India. -Mountain Research and Development 17:159-168.

[20] Paquette, A.J., Hawryshyn, A., Senikas, V., Potvin, C. (2009): Enrichment planting in secondary forests: a promising clean development mechanism to increase terrestrial carbon sinks. -Ecol. Soc. 14(1):31.

[21] Ramakrishnan, P.S. (2001): Ecology and sustainable development. New Delhi, India: National Book Trust of India.

[22] Sharma, C.M., Gairola, S., Ghildiyal, S.K., Suyal, S. (2009): Forest resource use patterns in relation to socioeconomic status. -Mountain Research and Development 29:308-319.

[23] Singh, J.S. (1981): Rural ecosystems and development in the Himalaya. - In: Singh, J.S., Singh, S.P., Shastri, C. (Eds.) Science and Rural Development in Mountains, Gyanodaya Prakashan, Nainital, India, pp 74-87.

[24] Singh, V., Thadani, R., Tewari, A., Ram, J. (2014): Human Influence on Banj Oak (Quercus leucotrichophora A. Camus) Forests of Central Himalaya. -Journal of Sustainable Forestry 33:373-386.

[25] Troup, R.S. (1921): Silviculture of Indian Trees. Vol. I-III. -Clarendon Press, Oxford

[26] UNFCCC [United Nations Framework Convention on Climate Change]. (1993): The United Nations Framework Convention on Climate Change, UN

[27] Yadav, R.P., Bisht, J.K., Pandey, B.M. (2015): Above ground biomass and carbon stock of fruit tree based land use systems in Indian Himalaya. -The Ecoscan 9(3\&4): 779-783.

[28] Yadav, R.P., Bisht, J.K. (2013): Agroforestry: A way to conserve MPTs in North Western Himalaya. -Res. J. Agriculture and Forestry Sci. 1(9): 1-7.

[29] Yadav, R.P., Bisht, J.K. (2014): Agroforestry to combat climate change. -Kheti 66: 11-14.

[30] Zobel, B.D., Singh, S.P. (1997): Himalayan Forests and Ecological Generalizations. -Bio Science 47(11):735-745. 